\title{
The influence of school leadership and teacher performance on the learning achievement of middle school students
}

\author{
Dhidhik Eni Rustiyah ${ }^{1}$, Nur Ahyani ${ }^{2}$, Dessy Wardiah ${ }^{2}$ \\ ${ }^{1}$ Sekolah Menengah Atas Negeri 2 OKU, Indonesia \\ ${ }^{2}$ Universitas PGRI Palembang, Indonesia
}

\begin{tabular}{l} 
Article Info \\
\hline Article history: \\
Received Jul $13^{\text {th }}, 2021$ \\
Revised Aug $15^{\text {th }}, 2021$ \\
Accepted Aug $30^{\text {th }}, 2021$ \\
\hline
\end{tabular}

\section{Keyword:}

Leadership

Performance

Achievement

\begin{abstract}
This study aims to determine and describe the influence of principal leadership and teacher performance on student achievement in SMA NegeriLubuk Raja OganKomeringUlu (OKU) District. The method used is a quantitative method. The data collection technique used was a questionnaire. The results of the study can be concluded that the test results show that the higher the effective leadership of the principal, the higher the student achievement squared the correlation coefficient between the two variables is 0.588 . The square of the correlation coefficient between the two variables (r2y2) of 0.5069 can be interpreted that if other variables are not controlled, then $50.69 \%$ of the proportion of student achievement variance can be explained by the level of teacher performance. and the multiple correlation coefficient between the two independent variables with the dependent variable Ry.12 of 0.684 . From the correlation coefficient, the coefficient of determination (R2) of 0.684 means that $68.40 \%$ of the proportion of student achievement variants can be explained jointly by the principal's leadership and teacher performance.
\end{abstract}

(C) 2021 The Authors. Published by IICET.

This is an open access article under the CC BY-NC-SA license

(https://creativecommons.org/licenses/by-nc-sa/4.0

\section{Corresponding Author:}

Rustiyah, D. E.,

Sekolah Menengah Atas Negeri 2 OKU, Indonesia

Email: dhidhikeni00@gmail.com

\section{Introduction}

National education serves to develop the ability and form the character and civilization of a dignified nation in order to enlighten the life of the nation, aims to develop the potential of learners to become human beings who believe and fear the Almighty God, virtuous, healthy, knowledgeable, speaking, creative, independent and to be a democratic and responsible citizen.

Schools as formal educational institutions must be able to develop all the potential that students have. The potential possessed by these students must include cognitive, affective and psychomotor aspects. In fulfilling the increasing expectations and desires of society, schools as educational organizations must strive to assess their strengths and weaknesses by making continuous improvements and identifying various challenges and threats in improving student learning outcomes.

Schools with professional leaders and supported by teachers who have high performance are expected to produce learning outcomes as expected. Quality learning can only be realized by teachers who have superior abilities and high motivation in carrying out their obligations. The key to the success of schools lies in the synergic collaboration between the principal and teachers, educators, parents, and the government. 
Teachers have a strategic role because their existence is closely related to the success and quality of education.In an effort to increase teacher awareness of the importance of improving professionalism and quality of work, the principal must conduct supervision of teachers to improve teacher performance, this is because low teacher performance will make the principal upset. The low performance of teachers can reduce the quality of education and hinder the achievement of the vision and mission in a school. Schools like this will not be able to produce graduates who are superior and have competitiveness in the global arena as it is today.

The principal is a supervisor who must act as a democratic, authoritative leader, and be a role model for all teachers, all students and all school employees.For this reason, the leadership role of the principal and teachers and teacher performance is to improve the quality of teacher teaching to be better than before. For this reason, the leadership of the principal and teachers in SMA must be applied as a guide in carrying out the teaching and learning process to make it more effective and efficient.

The principal as the leader of an educational institution has a big role in creating a conducive atmosphere in his work environment. This conducive atmosphere is an important factor in creating outstanding teachers. Teachers as educators have a very important role in the progress of the nation, teachers are one of the determining factors for the success of education. "Education personnel, especially teachers, are the soul of the school".

Therefore, increasing the professionalism of education personnel starting from needs analysis, planning, development, performance evaluation, work relations to remuneration, is an important work for a principal. Teachers play a very important role in determining the quality of school graduates. This means that to produce quality graduates, teachers with maximum quality and achievement are needed. Meanwhile, teachers with maximum quality and achievement can be obtained if supported by good leadership.

The teacher is one of the human components in the teaching and learning process, which plays a role in efforts to form potential human resources in the field of development. Quality education is very dependent on the existence of qualified teachers.

High teacher performance is a manifestation of teacher quality. This is quite important in order to achieve school goals. With high performance means that teachers can function as educators who are effective and effective in accordance with the goals they want to achieve. If the goal of improving the performance of teachers can be fulfilled, the goal of improving the quality of education will be achieved well. However, the problem that occurs in schools, including high school, is the fact that school students have almost the same human resource capabilities, namely low discipline and even low academic ability

Based on research conducted by [1], In addition, the available graduation data and UAN scores indicate that nationally the learning outcomes of school students are lower than general schools. The proportion of school students who did not pass the final examination was $7-10 \%$ greater than the proportion of general school students, although the national average scores for all subjects were still below the two types of education. This empirical data means that the results of teaching and learning in various fields of study have proven to be unsatisfactory for various parties.

Based on the description above, of course it is necessary to make efforts to improve school performance so that schools are more able to optimize their educational services to students, meet community expectations, and can keep up with developments in science and technology so that schools become educational institutions that deserve to be taken into account for their quality. Therefore, SMA requires integrated management both by the principal as a controller of activities in the school and by the teacher as implementing teaching and learning activities. Good coordination between school principals and teachers will support the creation of supportive teacher performance so that school goals will be achieved properly.

Based on the description above, the researcher will conduct a study entitled "The Influence of Principal Leadership and Teacher Performance on Student Achievement of Public High School Students in Lubuk Raja OganKomeringUlu (OKU) District.

The word leadership comes from the word "leader" which can be prefixed with the suffix that contains the work. In the Indonesian dictionary, the word "leader" has a meaning that is closely related to the meaning of pioneering walking in front, demanding, guiding, encouraging, taking the first steps and initiatives, moving ahead, acting first, giving examples, mobilizing others through influence.

Leadership is the ability to give constructive influence to others to make a cooperative effort to achieve the goals that have been planned. Leadership is a person's ability to move, direct, and at the same time provide a 
mindset, how each member works to be independent at work, especially in making decisions to accelerate the goals that have been set.

According to [2] leadership is a science and art that influences people or groups to act as expected to achieve goals effectively and efficiently.Leadership is translated from English "Leadership". is an applied science of social sciences, because the principles of the formula are expected to bring benefits to human welfare.According to [3], the definition of leadership continues to change according to the role it plays, the ability to empower subordinates / members so that initiatives to be creative in work arise and the results are more meaningful for the organization with the leader occasionally directing, grinding and influencing members.According to [4], leadership is the ability to influence a group towards certain achievements.

[5] leadership is basically a pattern of relationships between individuals who use authority and influence groups of people to work together. to achieve goals.According to Andang(2014)[6]leadership is a process carried out to influence a person or group of people to work together without coercion in achieving the goals of an organization.

Researchers typically define leadership according to individual perspectives and aspects of the phenomena that interest them most. Leadership has been defined in terms of individual characteristics, behavioral influences on others, patterns of interaction, role relationships, place in an administrative position, and perceptions by others about the validity of influence.Sobirin (2018)[7] explained that leadership is a process where someone with the help of their persuasive qualities influences organized group activities in an effort to achieve predetermined goals. From some of the definitions of leadership above, it can be concluded that leadership is a person's ability or ability in a group interaction process that influences others to achieve common goals effectively and efficiently.

Etymologically, the principal is the equivalent of the school principal who is in charge of running the principalship.The principal can be defined as a functional teacher who is given the task to lead a school where the teaching and learning process is held or a place where there is an interaction between the teacher who gives lessons and students who receive lessons.According to [8] the principal of the school is an additional position for a teacher. this is based on SK Mempan No. 0296 of 1996 which states that the principal is the official leader in the school, because there is legitimacy from the ruling and authorized parties either from the government or theSobirin (2018) foundation explains that the principal is a person who is responsible for various fields of work, namely the academic field, the field of staffing, the field student affairs, the field of facilities and infrastructure, the field of finance, and the field of public relations.

From some of the definitions above, it is concluded that the principal's leadership is the ability to create the most effective changes in group behavior for others by someone who is responsible for his or her profession. According to [9] " teacher performance can be interpreted as the level of success of teachers in carrying out educational tasks in accordance with their responsibilities and authorities based on performance standards that have been set for a certain period in the framework of achieving educational goals Understanding student achievement based on the opinion of [10] is a change in students which is shown in various forms such as changes in knowledge, skills, skills, and changes in other aspects that exist in learning individuals.

This research is also strengthened by previous research conducted by Sutoyo, Arafat and Fitriani (2020)[11] entitled "Principal Leadership in Improving Teacher Work Ethics in Primary Schools". The results showed that: 1) The leadership of the principal in improving the work ethic of teachers at SD N 17 PulauRimau has been carried out in various ways such as trying to create a conducive work environment, good cooperation for each school component, providing appropriate salaries, communicating and providing adequate facilities for both teachers and students in the learning process, 2) Work discipline at SD N 17 PulauRimau has been implemented by the teacher, but it is still running for some who lack discipline in attending due to various reasons and interests of each individual, 3) Principal has played its role to improve teacher morale. This is clarified by supports such as trying to create a comfortable learning environment, paying attention to the needs of teachers, and providing opportunities for all teachers to improve their competence.The similarity of research with previous research is that both study the leadership of school principals. Whereas the research of this researcher in previous research lies in the research variables. For previous studies that studied teacher ethics, while the current research examines teacher performance. 


\section{Method}

\section{Types of Research}

This study uses quantitative methods to view the partial effect of the variables that exist (Sugiyono, 2016). The quantitative research variables tested in this study consisted of school head leadership (X1) and Teacher Performance (X2) on Student Learning Achievement (Y), while hypothesis testing jointly (simultaneously) was principal leadership (X1) and teacher performance ( X2) on Student Learning Achievement (Y), then all data obtained is processed and processed with quantitative analysis. As for seeing the relationship between variables, it can be seen in chart 3.1 below:

\begin{tabular}{|l|l|}
\hline $\begin{array}{l}\text { Independent Variable (X) } \\
\text { X1 } \\
\text { (LeadershipHeadmaster) } \\
\text { X 2. } \\
\text { (Teacher Performance) }\end{array}$ & $\begin{array}{l}\text { Bound } \\
\text { Variable (Y) } \\
\text { Student } \\
\text { achievement }\end{array}$ \\
\hline
\end{tabular}

Figure 1<Model Constellation Path Between Variables $>$

\section{Research Subjects and Data}

This research was conducted in SMA Negeri 2 OKU and SMA Negeri 14 OKU in the LubukRaja OganKomeringUlu (OKU) sub-district. This school was chosen by the researcher because of several considerations, namely the school has adequate criteria for research. The population in this study were all students of class XII SMA Negeri 2 OKU and SMA Negeri 14 OKU. The population selection class XII with the consideration that class XII is the highest class so that they know more about the leadership of the principal and teacher performance and learning outcomes during school learning than lower class students. Based on the total population used, if the total population is 376 people, the sample for this study is 193 people.

In accordance with the approach used is a quantitative approach, the data collection technique used in this research is by means of a questionnaire. In this study, the data collection used was a closed questionnaire. The questionnaire was used to reveal data with the respondents of class XII SMA Negeri in OganKomeringUlu District. The measurement scale to be used is an ordinal scale, using a Likert scale as the measurement scale.

Before the analysis is carried out, the analysis requirements are first tested, which is a requirement that must be met so that the analysis can be carried out, both for predictive purposes and for hypothesis testing. There are 3 conditions that must be met before conducting regression analysis, namely 1) normality test; 2) homogeneity test; and 3) linearity test.

The normality test is used to determine the variables in this study, namely the independent variable and the dependent variable, both of which have a normal distribution or not. To test the normality of data distribution, according to Santoso(2017)[12], the Kolmogorof-Smirnov test from the Statical Program for Social Science for window version 21.0 program can be used.The normality of the data distribution is calculated by comparing the Asymtotic Significance value obtained with the value $=0.05$. If Asymp. Sig. $>0.05$, then the data is declared normal.

Furthermore, the linearity test is used to determine whether the path obtained is "meaningful" when it is used to make conclusions between the variables being analyzed. Testing the linearity of the independent variables with the variables being analyzed. The linearity test of the independent variables and the dependent variable was carried out using One-way Anova on the SPSS program with a significance level of $5 \%$. Interpretation of data linearity is carried out provided that if $\mathrm{F}$ counts $<\mathrm{F}$ table, then the independent variable with the dependent variable has a linear relationship.

\section{Results and Discussions}

Based on the research data obtained, then the data is processed in the form of descriptive statistical analysis. This analysis was conducted to determine the description of the principal's leadership variable (X1), and teacher performance (X2) on student achievement $(\mathrm{Y})$ in SMA Lubuk Raja OganKomeringUlu District. 
Before performing multiple linear regression analysis, first a classic assumption test is carried out so that the regression results used to predict the dependent variable are not biased. The classic assumption tests are:

\section{Normality Test}

Before the data is final analyzed for hypothesis testing, first the normality test is carried out using the Kolmogrof Smirnov Goodness of Fit Test with the help of the SPPS 21 computer software. Data is declared normally distributed if the significance value is more than $\alpha=0.05$. The results of the normality test are in Table 1 below:

\section{Tabel $1<$ NPar Tests $>$}

\section{One-Sample Kolmogorov-Smirnov Test}

$\mathrm{N}$

Normal Parameters ${ }^{\mathrm{a}, \mathrm{b}}$

Most Extreme Differences

Test Statistic

Asymp. Sig. (2-tailed)

a. Test distribution is Normal.

b. Calculated from data.

c. Lilliefors Significance Correction.
Unstandardized Residual

193

Mean

.0000000

Std. Deviation

11.31201831

Absolute

.059

Positive $\quad .028$

Negative $\quad-.059$

.059

$.095^{\mathrm{c}}$

Based on the output of the Kolmogorov Smirnov Goodness of Fit Test in Table 4.10, a significance value of 0.095 is obtained, which is greater than $\alpha=0.05$, the research data is normally distributed.

\section{Linearity Test}

Linearity test aims to determine whether the variables in this study have a significant linear relationship or not. The data linearity test criteria in this study are as follows:

Ho:Data has a significant linear relationship,if Fcount $<$ Ftable value

$\mathrm{Hi}$ :Data does not have a significant linear relationship,fFcount $<$ Ftable value

From the results of the calculation of the normality test, the following results are obtained:

Table $2<$ Measures of Association X2 dan $\mathrm{Y}>$

\begin{tabular}{|c|c|c|c|c|}
\hline & $\mathrm{R}$ & R Squared & Eta & Eta Squared \\
\hline$y * x 2$ & .288 & .083 & .512 & .262 \\
\hline
\end{tabular}

The results of the calculation for testing the linearity of the principal's leadership variable data and the student learning achievement variable data obtained by the Fcount of 3.76. The value of Ftable with dk 193 at $\alpha=0.05$ is 1.652 and a significance value of 0.995 . Because F2count $<$ Ftable and $0.995>0.05$, Ho is accepted. This means that there is a significant linear relationship between the principal's leadership variable (X1) and the Student Learning Achievement variable (Y).

The results of the calculation for linearity testing of teacher performance variable data and student learning achievement variable data obtained Fcount of 1,846 . The value of Ftable with $\mathrm{dk} 193$ at $\alpha=0.05$ is 1.652 and a significance value of 0.152 . Because F2count $<$ Ftable and $0.152>0.05$, Ho is accepted. This means that there is a significant linear relationship between the teacher performance variable (X2) and the student learning achievement variable (Y). Based on the values of Fcount and Ftable and the significance value above, it can be concluded that the pair of all good data between the principal leadership variable (X1) and the teacher performance variable (X2), and the Student Learning Achievement variable (Y) have a significant linear relationship. 


\section{Research Hypothesis Testing}

Hypothesis testing is carried out in order to test the correlation between the variables as well as to find out how much correlation between the independent variables and the dependent variable. The hypothesis is a provisional assumption of the problem formulation. Therefore, the hypothesis must be tested for empirical truth. Testing hypotheses 1 and 2 in this study using multiple linear regression analysis with $t$ test and $F$ test with the help of the SPSS for Windows 21 program. The results of regression analysis with the Student Achievement variable as the dependent variable and the principal leadership variable and teacher performance as independent variables are the regression equation is as follows: $\mathrm{Y}=61,420+0.466 \mathrm{X} 1+0.497 \mathrm{X} 2$

Based on SPSS calculations, the t test value (2.044) is greater than the t-table alpha $0.05(\mathrm{df}=35)$ of 1.679 . So it can be concluded that the principal's leadership has an effect on student achievement. The regression coefficient value for the principal leadership variable is 0.466 , which means that the principal leadership variable has an influence on teacher performance, that is, if there is an increase of 1 unit of the principal's leadership variable, it will increase the value of the Student Learning Achievement variable by 0.466 units. It can also be interpreted that the better the principal's leadership, the student's learning achievement will increase. Based on this analysis, it can be concluded that the principal's leadership has an effect on the Learning Achievement of Public High School Students in Lubuk Raja District, OganKomeringUlu Regency (OKU).

Based on the explanation of the $t$ test results above, it can be concluded that hypothesis 1 is accepted. Namely, the leadership of the principal affects the Student Achievement of SMA Lubuk Raja OganKomeringUlu (OKU) District. This explains that the principal's leadership contributes and influences the achievement of learning outcomes. A good leader will project himself in the form of a leadership attitude, behavior and leading activities that are developed in his educational institution, will affect the work situation, the morale of the members, the nature of human relations between others will affect the work results that can be achieved by the educational institution. (Qomaruddin, 2020)[13].

Based on the SPSS calculation in table 4.11, the $t$ test value (4.132) is greater than the table alpha 0.05 (df $=35$ ) of 1.679 , it can be concluded that teacher performance has an effect on teacher performance. The regression coefficient value for the teacher performance variable is 0.497 , meaning that the teacher performance variable has a positive influence on student achievement, that is, if there is an increase of 1 unit of teacher performance, it will increase the value of the Student Learning Achievement variable by 0.497 units. It can also be interpreted that the better the teacher's performance, the student's learning achievement will increase.

Based on this analysis, it can be concluded that hypothesis 2 is accepted, namely that teacher performance affects Student Achievement in SMA Lubuk Raja OganKomeringUlu (OKU) District. It can be concluded that teacher performance contributes and affects student achievement. That teacher performance is a very supportive contribution to the learning process for students and discipline is emphasized because the higher the discipline a teacher has, the better the teacher's performance.

In response to further the findings of this study, mainly related to theoretical studies on the importance of teacher performance. Teachers in schools have an important role in creating high-achieving students, so the performance of teachers in education units needs to be seen from various aspects, not only planning learning, implementing learning and evaluating student learning achievement, but also the dimensions of the teacher's competence. According to [14] said that "The success of learning is closely related to the performance of teachers who carry out their duties. Thus, teacher performance has an effect on student achievement in school.

Ha 1: Principal leadership and teacher performance jointly affect student achievement. Based on the SPSS calculation in table 4.10, the F test value (8.662) is greater than the F table alpha 0.05 (df1 $=\mathrm{k}-1=2$, df $2=\mathrm{n}$ $\mathrm{k}=42$ ) of 2.43 . So it can be concluded that hypothesis 1 is accepted, namely that the principal leadership and teacher performance jointly affect the Student Achievement of High School Students in Lubuk Raja OganKomeringUlu (OKU) District.

Then the $\mathrm{R}$ square value is 0.588 which means the coefficient of determination is $58.8 \%$. This means that the amount of influence together with the principal's leadership variable and teacher performance is $58.8 \%$, and the remaining $41.2 \%$ is influenced by other variables not examined in this study.

This is reinforced previous relevant research was carried out by Previous research was also conducted by [15] with the title "The Effect of Principal Leadership and School Committee Participation on Teacher Performance". Based on the research results described above, it can be concluded that the principal's leadership has a significant effect on teacher performance at SMA NegeriMuaraEnim; school committee participation has a significant effect on teacher performance at SMA NegeriMuaraEnim; and principal 
leadership and school committee participation together have a significant effect on the performance of SMA Negeri teachers in MuaraEnim. Similarities This research with previous research both examines the performance of teachers and the leadership of school principals, while the difference lies in other research subjects, for previous research it was focused on the school committee while for current research it is focused on student learning achievement.

\section{Conclusions}

From the research results it can be concluded that the results of testing the first hypothesis can be concluded that there is an influence between the principal's leadership on student achievement. The conclusion shows that the higher the effective leadership of the principal, the higher the student achievement, the results of testing the second hypothesis can be concluded. that there is an influence between teacher performance on student achievement. The conclusion shows that the higher the teacher's performance, the higher the student achievement and the results of testing the third hypothesis it can be concluded that there is an influence between the principal's leadership and teacher performance together. on student achievement. The conclusion shows that the more effective the principal's leadership is and the higher the teacher's performance, the higher the student's learning achievement.

\section{References}

Listyasari, E. (2013). PengaruhKepemimpinanKepalaSekolahDan Kinerja GuruTerhadapPrestasiBelajarSiswa di SMANegeri Se Kota Tasikmalaya. JurnalImiahMahasiswaPascasarjanaAdministrasiPendidikan. Volume 1.Nomor 1. Hal 9 - 16

Musbikin, I. (2013). MengatasiKanakalanSiswaRemaja. Pekanbaru: Zanafa Publishing

Wahyudi. (2015). KepemimpinanKepalaSekolahDalamOrganisasiPembelajar (Learning Organization). Bandung : Alfabeta

Damin, S danSuparno. (2019). ManajemendanKepemimpinanTransformasionalKekepalasekolahan. Jakarta: RinekaCipta

Suprihatiningrum, J. (2014). Guru ProfesionalPedomanKInerja, Kualifikasi\&Kompetensi Guru. Jogjakarta : ArRuzz Media

Andang. (2014) ManajemendanKepemimpinanKepalaSekolah .Yogyakarta :Ar - Ruzz Media.

Sobirin. (2018). KepalaSekolah, Guru danPembelajaran. Bandung : NuansaCendekia

Permadi, D danArifin, D. (2018). KepemimpinanTransformasionalKepalaSekolahdanKomitesekolah. Bandung : PT. SaranaPancaKarya Nusa

BarnawidanArifin, M. (2014). Kinerja Guru Profesional: InstrumenPembinaan, PeningkatandanPenilaian. Ar- Rusz M edia : Yogyakarta

Sudjana, N. (2011).PenilaianHasil Proses BelajarMengajar. Bandung: PT RemajaRosdakarya.

Sutoyo S., Arafat Y., danFitriani Y. (2020). Principal's Leadership in Improving Teacher's Work Ethic in Primary School. International Journal of Progressive Sciences and Technologies (IJPSAT) ISSN: 2509-0119.

Santoso, S. (2017). StatistikMultivariatdengan SPSS. Jakarta : PT. Gramedia

Qomaruddin, NNF.,\&Jaenuddin M. 2020. PengaruhKepemimpinanKepalaSekolahdanKinerjaGuru terhadapPrestasiPesertaDidik di MA NurulFurqonKecamatan Cibinong Kabupaten Bogor. JurnalDirosahIslamiyah. Vol 1 No 2 Hal 149- 163

Mulyasa,E. (2017). UjiKompetensidanPenilaianKinerja Guru. Bandung : PT. RosdaKarya

Imansyah, Arafat,Y\&Wardiah,D,. 2020. Pengaruh Kepemimpinan Kepala Sekolah dan Partisipasi Komite Sekolah Terhadap Kinerja Guru. JMKSP (Jurnal Manajemen, Kepemimpinan, dan Supervisi Pendidikan). Vol 5 No 2 P-ISSN:2548-7094 E-ISSN 2614-8021 